\title{
Both Typical and Atypical Long-Acting Injectable Antipsychotics in Bipolar Disorder: A Retrospective Chart Review
}

\author{
Gokay Alpak², Bahadir Demir², Ihsan Aksoy², Hilal Kaya², Ahmet Unal³, \\ Feridun Bulbul', Haluk A. Savas ${ }^{4}$
}

\section{ÖZET:}

Uzun etkili tipik ve atipik antipiskotiklerin iki uçlu bozukluk hastalarında kullanımı: Geriye dönük dosya taraması

Amaç: ikiuçlu bozukluk (iUB) tanı ve tedavi sürecinde zorluklar içeren ve kronik seyir gösteren psikiyatrik bir bozukluktur. iUB idame tedavisinde en büyük sorunlardan biri ilaç uyumunun sag̃lanmasıdır. Uzun etkili enjektabl (UEE) antipsikotikler bu tür hastalarda ciddi avantajlar sag̃lamaktadır. Biz bu çalışmada, tipik ve atipik UEE antipsikotikleri tedavi öncesi ve sonrasındaki bir yıllık dönemde klinik özellikler, hastane yatıș sayıları ve yan etkiler açısından ауг ауг karşılaştırmayı amaçladık.

Yöntem: Çalışma evreni Gaziantep Üniversitesi Duygudurum Birimi'nde takip edilen 802 iuB hastasından oluşturuldu. Bu hastalardan $80^{\prime}$ i tipik ya da atipik UEE antipsikotik kullanıyordu. Çalışma kriterlerini karşılayan sadece 31 hasta çalıșmaya dahil edildi. Etkinlik; tedavi öncesi ve sonrası bir yıllık dönem içindeki KGI, YMDÖ, HAMD skorları (12 ay önce, 6 ay önce, tedavi ekleme zamanı, 6 ay sonra ve 12 ay sonra), hastaneye yatıs oranları ve ortalama yıllık hecme sayıları karşılaștııılarak deg̃erlendirildi.

Bulgular: Çalıșma örnekleminde UEE antipsikotik kullanım oranı \%9.88 olarak tespit edildi. İdame tedavide UEE antipsikotiklerin yıllık ortalama atak sayısını azalttıg̃ı ve depresyondan ziyade manik atag̃ı önlemede etkin oldug̃u gösterildi. Atipik antipsikotiklerin YMDÖ ve KGI skorlarını anlamlı oranda azalttıg̃ı tespit edilirken HAMD skorlarında anlamlı bir deg̃ișiklik gözlenmedi. Tipik antipsikotikler ile ise ölçek skorlarının hiçbirinde anlamlı bir deg̃ișiklik görülmedi. Tipik ve atipik UEE antipsikotikler yan etkiler açısından tedavi öncesi ve sonrasında karşılaștıııldı̃̃ında anlamlı bir farkııık saptanmadı.

Tartıșma: Çalıșmamız bizim bilgilerimize göre, iUB'de atipik ve tipik UEE antipsikotiklerin birlikte dahil edildiḡi ilk çalıșmadır. Sonuç olarak; UEE antipsikotiklerin manik atak korumasında etkin olabileceg̃i ve yan etkiler açısından da tedavi öncesi ve sonrasında bir deg̃ișikliḡin olmadıg̃ı gösterilmiştir. Hasta sayısı artırılarak yapılacak yeni çalışmalarla çalışmamııın sonuçlarının tekrar edilmesine intiyaç vardır.

Anahtar sözcükler: uzun etkili antipsikotikler, tipik, atipik, iki uçlu bozukluk

Journal of Mood Disorders 2014;4(1):20-5

\section{ABSTRACT:}

Both typical and atypical long-acting injectable antipsychotics in bipolar disorder: a retrospective chart review

objective: Bipolar disorder (BD) is a chronic psychiatric disorder which shows difficulties in the process of diagnosis and treatment. One of the biggest problems in $\mathrm{BD}$ maintenance therapy is to ensure medication compliance. Long-acting injectable (LAI) antipsychotic medications have important advantages in such cases. In this study we aimed to include both LAl atypical and typical antipsychotics and to compare the clinical status, number of hospitalization, and side effects of pre and posttreatment periods of one year separately.

Methods: Our study sample was constituted of 802 BD patients whom are followed in Mood Disorders Unit of Gaziantep University. Among them 80 patients has been using typical or atypical LAI antipsychotics. In the context of the study criteria only 31 patients included in the study. Efficacy was assessed by the CGI, YMRS, HAMD scores of pre and post-treatment periods of one year (12 months ago, 6 months ago, treatment initiation time, 6 months later and 12 months later), by the rate of hospitalization, and by comparing the average number of mood episodes. Results: LAl antipsychotic usage rate was identified as $9.88 \%$ in the study sample. Both of the antipsychotics were shown to decrease the average number of episodes in one year, and effective in preventing manic episodes rather than depressive episodes. Atypical antipsychotics significantly decreased YMRS and CGI scores but a decrease in HAMD scores was not observed, whereas no significant changes were observed in all scale scores with typical antipsychotics. There were not any significant difference when typical and atypical LAl antipsychotics compared according to their side effects in pre and post-treatment periods.

Discussion: To the best of our knowledge, this is the first study that atypical and typical LAI antipsychotics were both included. As a result, it was shown that LAI antipsychotics may be effective in the prevention of manic episodes and there were not any differences found in terms of pre and post-treatment side effects. The results of our study are needed to be repeated in new studies with increased number of patients.

Key words: long acting antipsychotics, typical, atypical, bipolar disorder

Journal of Mood Disorders 2014;4(1):20-5

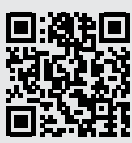

'MD, Assistant Professor of Psychiatry, ${ }^{2} \mathrm{MD}$, Psychiatry resident, ${ }^{3} \mathrm{MD}$, Associate Professor of Psychiatry, ${ }^{4} \mathrm{MD}$, PhD, Professor of Psychiatry, Department of Psychiatry, School of Medicine, Gaziantep University, Gaziantep-Turkey

Yazıșma Adresi / Address reprint requests to: Gokay Alpak,

Gaziantep University, Faculty of Medicine, 27310 Şahinbey, Gaziantep-Turkey

Telefon / Phone: +90-342-360-6060/76368

Faks / Fax: +90-342-360-3928

Elektronik posta adresi / E-mail address: gokayalpak@gmail.com

Kabul tarihi / Date of acceptance: 11 Mart 2014 / March 11, 2014

Bã̃ınt beyan

G.A., B.D., I.A., H.K., A.U., F.B., H.A.S.: Yazarlar bu makale ile ilgili olarak herhangi bir çıkar çatıșması bildirmemișlerdir.

Declaration of interest: G.A., B.D., I.A., H.K., A.U., F.B., H.A.S.: The G.A., B.D., I.A., H.K., A.U., F.B., H.A.S.:
authors reported no conflict of interest related to this article. 


\section{INTRODUCTION}

Bipolar disorder (BD) is a chronic psychiatric disorder which shows difficulties in the process of diagnosis and treatment (1). In studies, lifetime prevalence is estimated to be $4.5 \%$ (1). BD is a serious public health problem since it is widely seen with frequent relapses and recurrences causing high morbidity and high risk of suicide. Therefore it is the sixth disease leading to disability worldwide among those aged between 15-44 (2).

It has been reported that when BD patients left untreated, relapse rate exceeded $90 \%$ in the subsequent period of a manic episode $(3,4)$ whereas it exceeded $70 \%$ after a depressive episode $(4,5)$. Although the maintenance treatment had been continued for 5 years, relapse rate was more than $70 \%$. The most important reason was considered to be the partial or complete non-compliance to the treatment $(4,6)$. Basically, treatment for $\mathrm{BD}$ is divided into two stages as acute and maintenance treatment. Maintenance therapy is important in preventing of recurrence, suicide, psychosocial outcomes of episodes, and comorbid disorders (alcohol and substance use disorders) after treatment of acute episodes (7). Therefore, maintenance therapy should be planned beforehand with taking into consideration of the individual course of the illness. Existing data shows that the treatment in the acute phase would be also effective in the maintenance period (8).

One of the biggest problems in maintenance therapy is to ensure medication compliance. Patient and family education, social skills training, supportive interventions, community-based interventions, cognitive behavioral therapy, and as well as long-acting injectable (LAI) antipsychotics take place in daily practice in order to improve compliance (9). LAI antipsychotics have important advantages such as ensuring a stable blood level, reducing the risk of cessation of treatment, and preventing recurrences. Studies comparing the use atypical antipsychotics and mood stabilizers in maintenance therapy have not been revealed a significant difference in terms of efficacy $(10,11)$. A study conducted with BD patients in our center showed that LAI risperidone was effective in reducing the symptoms of manic episode and preventing the recurrence (12). Similarly in another study conducted with $\mathrm{BD}$ type I patients, LAI risperidone as maintenance therapy has shown to be effective to prevent the recurrence of manic episodes and it was indicated that it might increase the adherence to treatment (13). Flupentixol decanoate, a typical antipsychotic, was shown to decrease the recurrence of manic episode when used as maintenance therapy (14). Considering these findings, antipsychotics nowadays have begun to be defined as mood stabilizers $(10,11)$.

In this study we aimed to include both atypical and typical LAI antipsychotics and to compare the clinical status, number of hospitalization, and side effects of one year pre and post-treatment periods of one year separately.

\section{METHOD}

Our study population was constituted of 80 patients whom were diagnosed as BD I according to DSM-IV-TR and has been using LAI antipsychotics (zuclopenthixol decanoate, flupentixol decanoate, and risperidone) among $802 \mathrm{BD}$ patients registered and followed in Mood Disorders Unit of Department of Psychiatry at Gaziantep University. The study was designed as retrospective chart review. The study inclusion criteria were defined as; using a LAI antipsychotic at least one year and continue followups regularly at least one year before and after LAI antipsychotic initiation, not having mental retardation, and not having any substance abuse or dependency. In the context of the inclusion criteria 49 patients were excluded from the study; 22 of them were lacking sufficient follow-up data for one year before the LAI antipsychotic initiation and 27 of them were lacking sufficient follow-up data for one year after the LAI initiation. Data of the study was created with only 31 patients meeting the study criteria. Efficacy was assessed by the CGI, YMRS, HAMD scores of one year before and after treatment initiation (12 months ago, 6 months ago, treatment initiation time, 6 months later and 12 months later), by the rate of hospitalization and by comparing the average number of mood episodes in one year before and after the LAI antipsychotics initiation. Study was approved by the Ethics Committee of the University of Gaziantep.

\section{Screening Tools}

Clinical Global Impression (CGI) scales wer used to measure global improvement and severity. CGI-Severity (CGI-S) provides a rating of baseline severity ranging 
from 1 (not at all ill) to 7 (extremely ill). CGI-Improvement (CGI-I) provides a rating of clinical improvement ranging from 1 (very much improved) to 7 (very much worsened). The Clinical Global Impression - Efficacy Index is a 4 point $\times 4$ point rating scale that assesses the therapeutic effect of the treatment as 1, unchanged to worse; 2 , minimal; 3 , moderate; 4 , marked by side effects rated as none, do not significantly interfere with patient's functioning, significantly interferes with patient's functioning and outweighs therapeutic effect (15).

Young Mania Rating Scale (YMRS): It consists of 11 items and each of these items have five severity levels code as likert type. The validation of Turkish version of the scale made by Karadag et al in 2001 (16).

Hamilton Depression Scale (HAM-D) was published in 1960 by Max Hamilton and consists of 17 items. Items related with difficulty in sleeping, waking up at midnight, waking up early in the morning, somatic symptoms, genital symptoms, gastrointestinal symptoms and insight were rated between 0-2 and other items were rated between 0-4. Highest score is 53 . The reliability and validity of the scale was conducted by Akdemir and colleagues (17).

Statistical analyzes were performed with SPSS version 15.0. Wilcoxon and Friedman tests were used for comparing the groups. Kruskal-Wallis test was used when comparing the variables ( 3 or more) according to the typical and atypical antipsychotic usage. Statistically significant $\mathrm{p}$ value was considered as $<0.05$.

\section{RESULTS}

Sociodemographic characteristics are given in Table 1. Patients' ages ranged from 22 to 62 (mean: $33.97 \pm 10.87$ ). 26 patients (83.9\%) were using atypical antipsychotics, 5 patients $(16.1 \%)$ were using typical antipsychotics. At the beginning of LAI antipsychotic treatment, 25 patients $(80.7 \%)$ were in manic episode, 3 (9.7\%) were euthymic, 1 (3.2\%) was in depressive episode, 1 (3.2\%) was in mixed episode, and 1 (3.2\%) was in hypomanic episode. The average dose in patients using LAI risperidone was $39.5 \pm 9.3 \mathrm{mg}$.

All patients showed a statistically significant reduction in terms of YMRS, HAM-D, and CGI scores at pre and post-treatment $6^{\text {th }}$ and $12^{\text {th }}$ months $(\mathrm{p}<0.001, \mathrm{p}=0.001$ and $\mathrm{p}<0.001$ respectively). When typical and atypical antipsychotics were compared separately in terms of scales; atypical antipsychotics showed statistically significant reductions in YMRS and CGI scores, whereas typical antipsychotics showed no significant difference in all of the scales (Table 2). Changes of follow-up scores in pre and post-treatment periods of one year are presented in Figure 1, 2 and 3.

The rate of hospitalization was found to be decreased

\begin{tabular}{lcc}
\hline Table 1: Sociodemographic variables & \\
& Number (n) & Percentage (\%) \\
\hline Gender & & \\
$\quad$ Male & 21 & 67.7 \\
$\quad$ Female & 10 & 32.3 \\
Marital Status & & \\
$\quad$ Married & 10 & 32.3 \\
Single & 19 & 61.2 \\
$\quad$ Widowed & 2 & 6.5 \\
Education Level & & \\
Literate & 1 & 3.2 \\
Primary School & 9 & 29 \\
$\quad$ Middle School & 5 & 16.1 \\
High School & 9 & 29.1 \\
$\quad$ University & 7 & 22.6 \\
Long-acting antipsychotic & & \\
Risperidone & 26 & 12.9 \\
$\quad$ Zuclopenthixol & 4 & 3.2 \\
Flupentixol & 1 &
\end{tabular}
Table 2: Comparison of typical and atypical antipsychotics according to their effects on scale scores

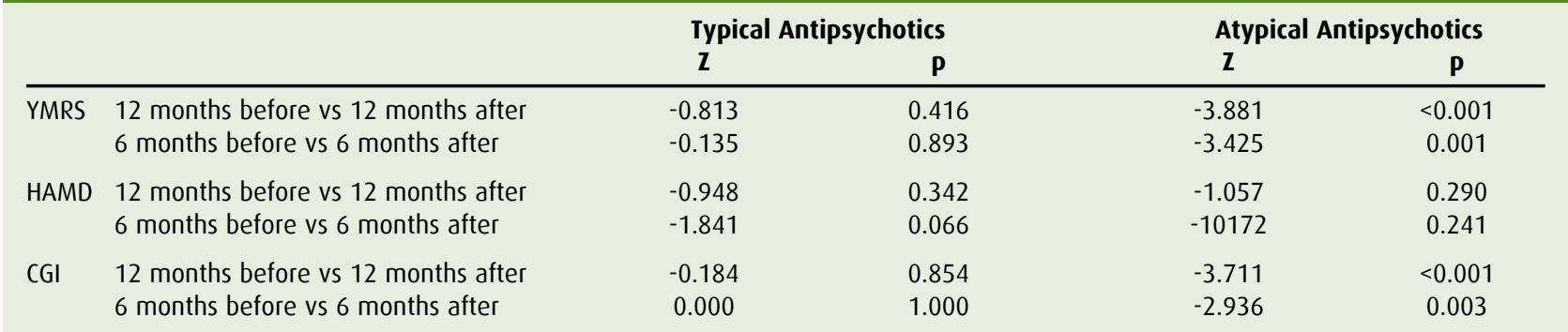



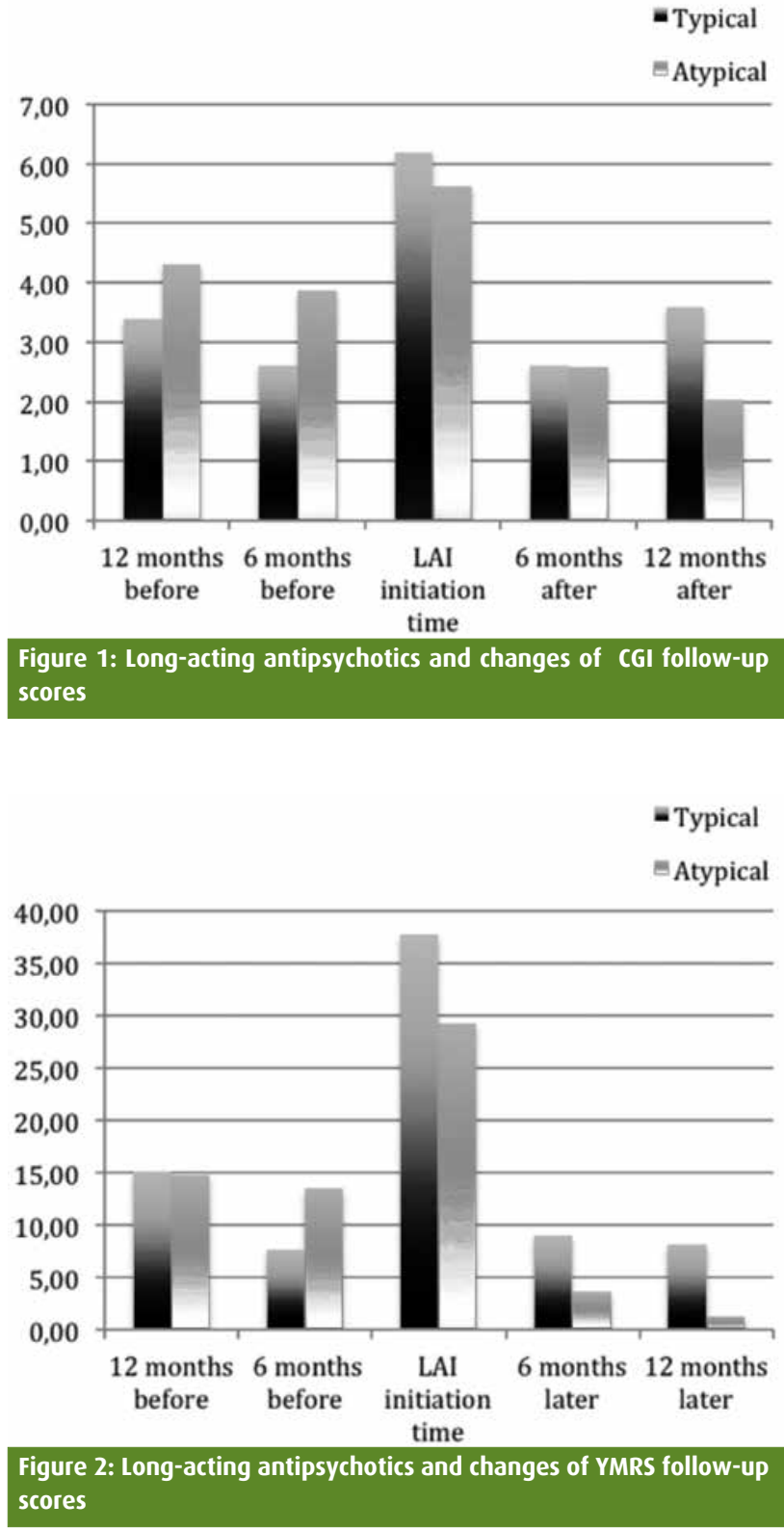

at $12^{\text {th }}$ month after the initiation of LAI antipsychotics (-4.484; $\mathrm{p}<0.001)$. Hospitalization rate did not differed significantly with typical antipsychotics (1.633; $\mathrm{p}=0.102$ ), but it was found to be significantly decreased with atypical antipsychotics $(-4.220 ; \mathrm{p}<0.001)$.

The mean of episodes in one year prior to use of LAI antipsychotics was $1.45 \pm 0.9$ while it was found as $0.32 \pm 0.4$ in one year after treatment $(\mathrm{p}<0.001)$. The mean of pretreatment manic episodes were $1.03 \pm 0.41$ in one year and post-treatment manic episodes were $0.23 \pm 0.76$ in one year. We found that typical and atypical antipsychotics had significantly reduced manic episode relapses in one

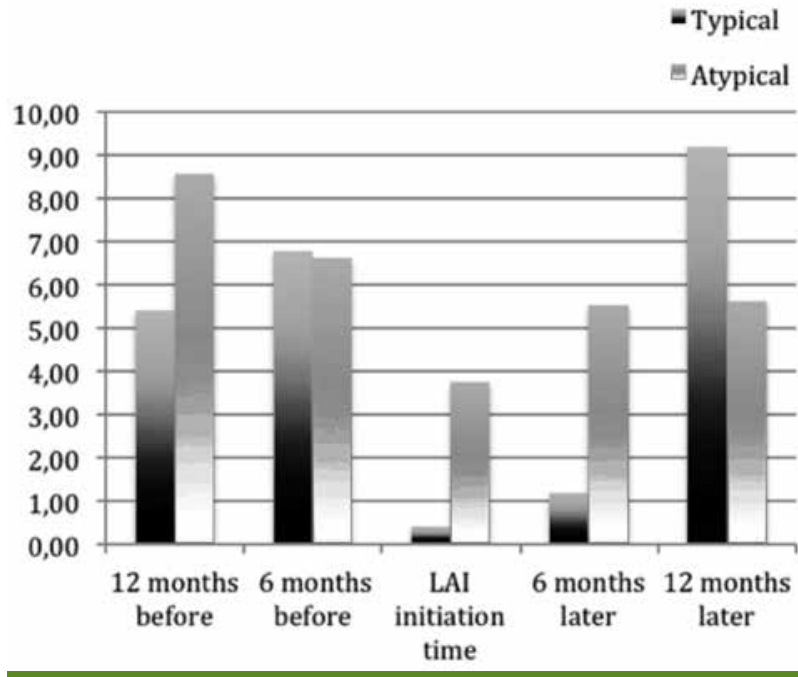

Figure 3: Long-acting antipsychotics and changes of HAMD followup scores

year $(-2.060 ; \mathrm{p}=0.039,-4.422 ; \mathrm{p}<0.001$ respectively). All the study group and moreover typical and atypical antipsychotics separately did not differ significantly according to side effects when compared with CGI side effect sub-scale pre and post-treatment periods of one year $(\mathrm{p}=0.739, \mathrm{p}=0.157, \mathrm{p}=0.257$ respectively).

\section{DISCUSSION}

In order to summarize the results of our study; (i) LAI antipsychotic usage rate was identified as $9.88 \%$ in the study sample, (ii) LAI antipsychotics as maintenance therapy were shown to decrease relapse rates in one year, (iii) LAI antipsychotics were found to be effective in preventing manic episodes, (iv) atypical antipsychotics significantly decreased YMRS and CGI scores but a decrease in HAMD scores was not observed, (v) no significant changes were observed in all scale scores with typical antipsychotics, (vi) no significant difference when typical and atypical LAI antipsychotics compared according to their side effects in pre and post-treatment periods.

LAI antipsychotic prescribing rates by psychiatrists for psychotic patients are still low $(<10 \%)$ in clinical practice (18). In our study, we detected similar rates of LAI antipsychotic usage in BD patients. Many reasons arising from psychiatrists, patients, and caregivers may be the cause of this low rates. Pain at the injection site, sense of being controlled, fear of stigmatization and late 
disappearance of side effects can be considered as common causes (19). In another study, negative attitudes of patients towards LAI antipsychotics has been reported to be associated with insufficient information given by their physicians (20). At this point, providing sufficient information to our patients, if possible with psychoeducation programs, about LAI antipsychotics which have important place in treatment of chronic diseases like BD may allow better treatment options for our patients.

In earlier studies, LAI antipsychotics had been shown to reduce and prevent mood episodes similar to the present study $(12,21,22)$. LAI risperidone was reported that it has a protective effect for manic episodes rather than depressive episodes (21-23). The results of our study were consistent with the literature in this aspect and we also found that typical antipsychotics might have a similar effect. Indeed, flupentixol decanoate, has been shown to reduce the mean of yearly episodes in patients with predominantly manic episodes (24).

There were no significant changes between pre and post-treatment scales with typical LAI antipsychotics were observed. Despite our study is the first study taking into consideration of changes in scales, the results of our study on this issue should be interpreted carefully since the small number of such patients $(n=5)$. Possible explanations of this result may stem from preferring typical LAI antipsychotic treatment in patients with relatively higher YMRS scores than atypicals, and number of patients included in the study.

\section{References:}

1. Merikangas KR, Akiskal HS, Angst J, Greenberg PE, Hirschfeld RM, Petukhova M, Kessler RC. Lifetime and 12-month prevalence of bipolar spectrum disorder in the National Comorbidity Survey replication. Arch Gen Psychiatry. 2007;64:543-52.

2. Murray CJ, Lopez AD. Evidence-based health policy--lessons from the Global Burden of Disease Study. Science. 1996;274:740-3.

3. Bowden CL, Calabrese JR, Sachs G, Yatham LN, Asghar SA, Hompland M, et al. Lamictal 606 Study Group. A placebocontrolled 18-month trial of lamotrigine and lithium maintenance treatment in recently manic or hypomanic patients with bipolar I disorder. Arch Gen Psychiatry. 2003;60:392-400. Erratum in: Arch Gen Psychiatry. 2004;61:680

4. El-Mallakh RS. Medication adherence and the use of long-acting antipsychotics in bipolar disorder. J Psychiatr Pract. 2007;13:7985.
Atypical antipsychotics showed milder side effects (25) and reduced the rate of side effects after switching from typical to atypical antipsychotics (25). In our study, the entire study sample showed no difference in terms of side effects before and after treatment even when evaluated according to the type of antipsychotic used. LAI antipsychotics, related with the technology that used in the production, are expected to be associated with lesser side effects than oral antipsychotics (26).

The small number of patients treated with typical LAI antipsychotics may be accepted as a limitation of our study. Similar studies also included limited number of such patients and it has been shown that atypical antipsychotics were being preferred instead of typical antipsychotics day by day (27). Retrospective design of the study and usage of CGI scores to assess the side effects instead of a specific scale may be accepted as other limitations.

\section{CONCLUSION}

To the best of our knowledge, this is the first study that atypical and typical LAI antipsychotics were both included. As a result, it was shown that LAI antipsychotics may be effective in the prevention of manic episodes and there were not any differences found in terms of pre and post-treatment side effects. The results of our study are needed to be repeated in new studies with increased number of patients.

5. Calabrese JR, Bowden CL, Sachs G, et al. A placebo-controlled 18-month trial of lamotrigine and lithium maintenance treatment in recently depressed patients with bipolar I disorder. J Clin Psychiatry. 2003;64:1013-24.

6. Coryell W, Endicott J, Maser JD, Mueller T, Lavori P, Keller M. The likelihood of recurrence in bipolar affective disorder: the importance of episode recency. J Affect Disord. 1995;33:201-6.

7. Eroglu MZ, Özpoyraz N. Long-term Treatment in Bipolar Disorder. Current Approaches In Psychiatry. 2010;2:206-36 (in Turkish).

8. Yatham LN, Kennedy SH, Parikh SV, Schaffer A, Beaulieu S, Alda M, et al. Canadian Network for Mood and Anxiety Treatments (CANMAT) and International Society for Bipolar Disorders (ISBD) collaborative update of CANMAT guidelines for the management of patients with bipolar disorder: update 2013. Bipolar Disord. 2013;15:1-44. 
9. Yıldız M, Yüksel AG. Why depot antipsychotic drug use in the treatment of psychotic disorders is still important? An investigation regarding clinical outcome. Bulletin of Clinical Psychopharmacology. 2006;16:98-103 (in Turkish).

10. Savas HA, Yumru M, Kaya MC, Selek S. Atypical antipsychotics as "mood stabilizers": a retrospective chart review. Prog Neuropsychopharmacol Biol Psychiatry. 2007;31:1064-7.

11. Fountoulakis KN, Vieta E, Sanchez-Moreno J, et al. Treatment guidelines for bipolar disorder: a critical review. J Affect Disord. 2005;860:1-10.

12. Savas HA, Yumru M, Ozen ME. Use of long-acting risperidone in the treatment of bipolar patients. J Clin Psychopharmacol. 2006;26:530-1.

13. Fagiolini A, Casamassima F, Mostacciuolo W, Forgione R, Goracci A, Goldstein BI. Risperidone long-acting injection as monotherapy and adjunctive therapy in the maintenance treatment of bipolar I disorder. Expert Opin Pharmacother. 2010;11:1727-40.

14. Ahlfors UG, Baastrup PC, Dencker SJ, Elgen K, Lingjaerde O, Pedersen V, et al. Flupenthixol decanoate in recurrent manicdepressive illness. A comparison with lithium. Acta Psychiatr Scand. 1981;64:226-37.

15. Guy W. Clinical Global Impressions ECDEU Assessment Manual for Psychopharmacology, Revised (DHEW Publ. No. ADM 76-338). National Institute of Mental Health: Rockville, MD. 1976:218-22.

16. Karadag F, Oral ET,Yalcın FA, Erten E. Reliability and Validity of Turkish Translation of Young Mania Rating ScaleTürk Psikiyatri Dergisi. 2001;13:107-14 (in Turkish).

17. Akdemir A, Örsel S, Dağ İ, et al. Reability, validity and clinical use of Hamilton Depression Rating Scale. Psikiyatri Psikoloji Psikofarmakoloji Dergisi. 1996;4:251-29 (in Turkish).

18. Hamann J, Mendel R, Heres S, et al. How much more effective do depot antipsychotics have to be compared to oral antipsychotics before they are prescribed? Eur Neuropsychopharmacol. 2010;20:276-9.
19. Glazer WM, Kane JM. Depot neuroleptic therapy: an underutilized treatment option. J Clin Psychiatry. 1992;53:426-33.

20. Jaeger M, Rossler W. Attitudes towards long-acting depot antipsychotics: A survey of patients, relatives and psychiatrists. Psychiatry Res. 2010;175:58-62.

21. Quiroz JA, Yatham LN, Palumbo JM, Karcher K, Kushner S, Kusumakar V. Risperidone long-acting injectable monotherapy in the maintenance treatment of bipolar I disorder. Biol Psychiatry. 2010;68:156-62.

22. Han C, Lee MS, Pae CU, Ko YH, Patkar AA, Jung IK. Usefulness of long-acting injectable risperidone during 12-month maintenance therapy of bipolar disorder. Prog Neuropsychopharmacol Biol Psychiatry. 2007;31:1219-23.

23. Benabarre A, Castro P, Sánchez-Moreno J, Martínez-Arán A, Salamero M, Murru A, Franco C, et al. Efficacy and safety of longacting injectable risperidone in maintenance phase of bipolar and schizoaffective disorder. Actas Esp Psiquiatr. 2009;37:143-7.

24. Ahlfors UG, Baastrup PC, Dencker SJ, Elgen K, Lingjaerde O, Pedersen V, et al. Flupenthixol decanoate in recurrent manicdepressive illness. A comparison with lithium. Acta Psychiatr. Scand 1981;64:226-37.

25. Virit O, Altindag A, Bulbul F,Savas HA, Dalkilic A. LongActing Typical and Atypical Antipsychotics in Treatment of Schizophrenia: A Retrospective Comparison. Bulletin of Clinical Psychopharmacology. 2009;19:119-27.

26. Samalin L, Charpeaud T, Lorabi O, Llorca P. Patient perspectives on use of long-acting antipsychotics in bipolar disorder: focus on risperidone injection. Patient Prefer Adherence. 2010;4:325-34.

27. Weiden PJ. Switching antipsychotics: an updated review with a focus on quetiapine. J Psychopharmacol. 2006;20:104-18. 